\title{
Cardioprotective Melatonin: Translating from Proof-of-Concept Studies to Therapeutic Use
}

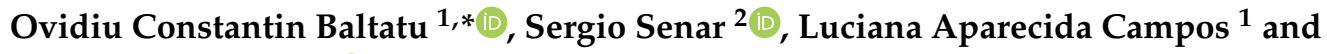 \\ José Cipolla-Neto ${ }^{3, * \mathbb{D}}$ \\ 1 Center of Innovation, Technology and Education (CITE), School of Health Sciences at Anhembi Morumbi \\ University, Laureate International Universities, Sao Jose dos Campos 12247-016, Brazil \\ 2 DrTarget, 28806 Madrid, Spain \\ 3 Department of Physiology and Biophysics, Institute of Biomedical Sciences, University of São Paulo, \\ São Paulo 05508-900, Brazil \\ * Correspondence: ocbaltatu@anhembi.br or ocbaltatu@gmail.com (O.C.B.); cipolla@icb.usp.br (J.C.-N.)
}

Received: 7 August 2019; Accepted: 4 September 2019; Published: 5 September 2019

\begin{abstract}
In this review we summarized the actual clinical data for a cardioprotective therapeutic role of melatonin, listed melatonin and its agonists in different stages of development, and evaluated the melatonin cardiovascular target tractability and prediction using machine learning on ChEMBL. To date, most clinical trials investigating a cardioprotective therapeutic role of melatonin are in phase 2a. Selective melatonin receptor agonists Tasimelteon, Ramelteon, and combined melatonergic-serotonin Agomelatine, and other agonists with registered structures in CHEMBL were not yet investigated as cardioprotective or cardiovascular drugs. As drug-able for these therapeutic targets, melatonin receptor agonists have the benefit over melatonin of well-characterized pharmacologic profiles and extensive safety data. Recent reports of the X-ray crystal structures of MT1 and MT2 receptors shall lead to the development of highly selective melatonin receptor agonists. Predictive models using machine learning could help to identify cardiovascular targets for melatonin. Selecting ChEMBL scores $>4.5$ in cardiovascular assays, and melatonin scores $>4$, we obtained 284 records from 162 cardiovascular assays carried out with 80 molecules with predicted or measured melatonin activity. Melatonin activities (agonistic or antagonistic) found in these experimental cardiovascular assays and models include arrhythmias, coronary and large vessel contractility, and hypertension. Preclinical proof-of-concept and early clinical studies (phase 2a) suggest a cardioprotective benefit from melatonin in various heart diseases. However, larger phase 3 randomized interventional studies are necessary to establish melatonin and its agonists' actions as cardioprotective therapeutic agents.
\end{abstract}

Keywords: melatonin; cardioprotection; cardiovascular system; drugs; machine learning; in silico

\section{Introduction}

Melatonin (N-acetyl-5-methoxytryptamine) is an indolamine with a molecular mass of $232.283 \mathrm{~g} / \mathrm{mol}$ that presents two basic properties: (1) It is amphiphilic (partition coefficient of 1.2), being almost equally diffusible in aqueous and in lipid medium so that it can be found in all compartments of the organism, and (2) it is a potent antioxidant molecule, efficiently scavenging almost any oxygen and nitrogen reactive species. Its origin, and supposedly its primary function, seems to be linked to this antioxidant potency that is well preserved throughout the phylogenetic tree. The other melatonin cellular and systemic functions and also different ways of action were acquired during evolution, according to the complexity of the organism and the site of melatonin production [1,2]. Synthesized from the amino acid tryptophan as the primary substrate, in complex organisms, in mammals, melatonin can be produced by several peripheral tissues for local use (autocrine/paracrine action), 
besides being produced by the pineal gland and released in the circulation, acting as a hormone. Melatonin's mechanisms of actions are mediated through receptor-dependent and non-receptor dependent (intracellular binding proteins and antioxidant effects) pathways (Figure 1). Melatonin acts as a biological time-domain molecule acting on the circadian, seasonal, and transgenerational timescales (Figure 1).

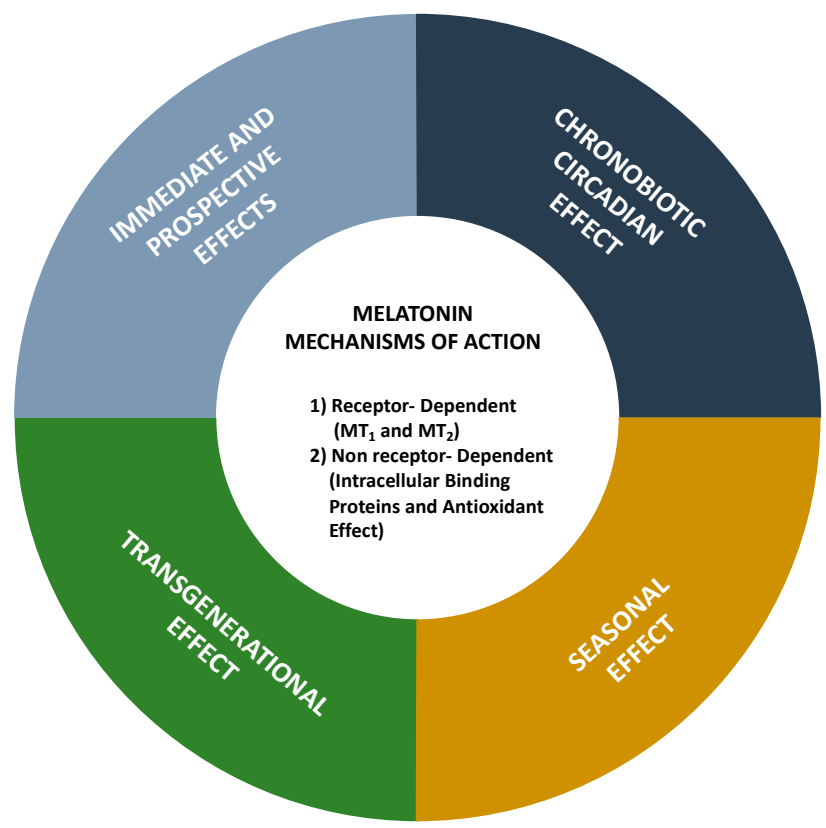

Figure 1. Melatonin mechanisms of action.

There are two specific melatonin membrane receptors, nominated MT1 (or MTNR1A) and MT2 (MTRN1B). They are protein-coupled receptors linked to Gi/Go or Gq/G11, and signaling, therefore, happens either through the inhibition of cAMP or cGMP synthesis or activation of phospholipase $\mathrm{C}$, depending on the central or peripheral localization of the target. These melatonin receptors are ubiquitously present in peripheral and central organs, including the cardiovascular system. MTNR1B mutations are associated with increased blood sugar levels and increased risk for type 2 diabetes, while variants in MTNR1A and B have been linked to autism spectrum disorders [3,4]. Due to its phylogenetic origin and its amphiphilicity, melatonin can also act in a nonreceptor-mediated way, regulating directly some intracellular biochemical processes. In this case, in addition to direct scavenging free radicals and free radical products, melatonin can interact with molecular effectors, such as the enzyme calcium/calmodulin-dependent kinase II. It should be pointed out that the well-known antioxidant effect of melatonin is, in part, dependent on its direct interaction with reactive species of oxygen and nitrogen, besides increasing receptor-mediated antioxidant expression.

Melatonin controls cardiovascular function (blood pressure and heart rate) acting either peripherally (heart and blood vessels) or centrally (hypothalamus, area postrema, caudal ventrolateral medulla, and/or the rostral ventrolateral medulla), in addition to regulating the renin-angiotensin system [5] and mitochondrial function [6].

A large preclinical portfolio suggests a cardioprotective role and other cardiovascular benefits of melatonin. Evidence for cardiovascular benefits of dietary melatonin has been recently reviewed [7]. Due to its pleiotropic actions on the cardiovascular system, melatonin has gained therapeutic interest for cardiac and cardiovascular patients [8].

In this review, we summarized the actual clinical data for a cardioprotective therapeutic role of melatonin, listed melatonin and its agonists in different stages of development, and evaluated the melatonin cardiovascular target tractability and prediction using machine learning on ChEMBL. 


\section{Clinical Trials with Melatonin in Heart Diseases}

\subsection{Acute Coronary Syndrome}

Acute coronary syndrome (ACS) contains three types of coronary artery disease: ST-segment elevation myocardial infarction (STEMI), non-ST-segment elevation myocardial infarction (NSTEMI), and unstable angina. Reasons for the use of melatonin in acute coronary syndrome have been reviewed by Dominguez-Rodriguez et al. [9,10]. Stipulated mechanisms for benefic effects melatonin in this pathology include vasodilatory effects of vascular melatoninergic receptors, antioxidative and anti-inflammatory actions, and influence on circadian cardiovascular rhythms [9,10]. Through these mechanisms, several preclinical studies have suggested melatonin as effective in reducing ischemia-reperfusion injury, including injury in the heart (reviewed by Reiter and Tan, [11]).

Although intravenous and intracoronary melatonin during primary percutaneous coronary intervention (PPCI) in patients with STEMI was not associated with a reduction in infarct size (Clinical trials: NCT00640094) [12], a significant effect appeared in a post hoc analysis for patients who presented early after symptom onset [13] (Table 1). 
Table 1. Clinical trials with melatonin in heart diseases.

\begin{tabular}{|c|c|c|c|c|c|}
\hline Target Disease, Reference & Objective & Study Phase & Study Design & Melatonin dosing & Outcomes \\
\hline Myocardial Infarction [12] & $\begin{array}{l}\text { Melatonin Adjunct in the Acute } \\
\text { myocaRdial Infarction Treated With } \\
\text { Angioplasty (MARIA)/NCT00640094 }\end{array}$ & 2 & $\begin{array}{l}\text { randomized, } \\
\text { double-blind, placebo } \\
\text { controlled trial }\end{array}$ & $\begin{array}{l}\text { Intravenous and } \\
\text { intracoronary melatonin } \\
\text { during primary } \\
\text { percutaneous coronary } \\
\text { intervention (PPCI). }\end{array}$ & $\begin{array}{l}\text { Negative: } \\
\text { melatonin in patients with STEMI was } \\
\text { not associated with a reduction in infarc } \\
\text { size and has an unfavourable effect on } \\
\text { the ventricular volumes and LVEF } \\
\text { evolution }\end{array}$ \\
\hline $\begin{array}{l}\text { ST-Elevation Myocardial } \\
\text { Infarction (STEMI) [13] }\end{array}$ & $\begin{array}{l}\text { Post hoc of MARIA } \\
\text { study/NCT00640094 }\end{array}$ & 2 & $\begin{array}{l}\text { randomized, } \\
\text { double-blind, placebo } \\
\text { controlled trial }\end{array}$ & & $\begin{array}{l}\text { Positive: } \\
\text { melatonin in patients with STEMI who } \\
\text { presented early after symptom onset was } \\
\text { associated with a significant reduction in } \\
\text { the infarct size after pPCI }\end{array}$ \\
\hline $\begin{array}{l}\text { Coronary artery bypass } \\
\text { grafting [14] }\end{array}$ & $\begin{array}{l}\text { Efficacy of melatonin in reducing early } \\
\text { reperfusion injury and acute oxidative } \\
\text { stress in patients undergoing coronary } \\
\text { artery bypass grafting (CABG). }\end{array}$ & 2 & $\begin{array}{l}\text { randomized, open-label, } \\
\text { placebo-controlled trial }\end{array}$ & & $\begin{array}{l}\text { Positive: } \\
\text { melatonin significantly reduced CABG } \\
\text { related cardiac injury and oxidative } \\
\text { stress. }\end{array}$ \\
\hline $\begin{array}{l}\text { ST-Elevation Myocardial } \\
\text { Infarction (STEMI) [15] }\end{array}$ & $\begin{array}{l}\text { To study whether the administration of } \\
\text { melatonin during acute myocardial } \\
\text { reperfusion improves myocardial } \\
\text { salvage assessed by cardiac magnetic } \\
\text { resonance imaging (CMR) in patients } \\
\text { with STEMI }\end{array}$ & 2 & $\begin{array}{l}\text { randomized, } \\
\text { double-blinded, placebo } \\
\text { controlled trial }\end{array}$ & $\begin{array}{l}\text { intracoronary or } \\
\text { intravenous melatonin } \\
\text { (total } 50 \mathrm{mg} \text { ) }\end{array}$ & $\begin{array}{l}\text { Negative: } \\
\text { melatonin did not improve the } \\
\text { myocardial salvage index. }\end{array}$ \\
\hline $\begin{array}{l}\text { Elective abdominal aortic } \\
\text { aneurism repair [16] }\end{array}$ & $\begin{array}{l}\text { To study the effect of perioperative } \\
\text { melatonin treatment on clinical cardiac } \\
\text { morbidity and markers of myocardial } \\
\text { ischemia in patients undergoing } \\
\text { elective surgery for abdominal aortic } \\
\text { aneurism }\end{array}$ & & $\begin{array}{l}\text { randomized, } \\
\text { placebo-controlled, } \\
\text { clinical trial }\end{array}$ & $\begin{array}{l}\text { infusion over a 2-hr } \\
\text { period either, } 50 \mathrm{mg} \\
\text { melatonin or placebo } \\
\text { intra-operatively, and } 10 \\
\text { mg melatonin or placebo } \\
\text { orally, the first three } \\
\text { nights after surgery. }\end{array}$ & $\begin{array}{l}\text { Positive: } \\
\text { melatonin decreased clinical cardiac } \\
\text { morbidity and the occurrence of } \\
\text { myocardial ischemia after abdominal } \\
\text { aortic aneurism repair. }\end{array}$ \\
\hline $\begin{array}{l}\text { Postural tachycardia } \\
\text { syndrome (POTS) [17] }\end{array}$ & $\begin{array}{l}\text { Tested the hypothesis that melatonin } \\
\text { will attenuate the tachycardia and } \\
\text { improve symptom burden in patients } \\
\text { with POTS. } \\
\text { NCT00262470 }\end{array}$ & 2 & $\begin{array}{l}\text { randomized, } \\
\text { single-blinded, crossover } \\
\text { trial }\end{array}$ & $\begin{array}{l}\text { melatonin } 3 \mathrm{mg} \text { orally and } \\
\text { placebo, on separate } \\
\text { mornings, in a } \\
\text { randomized crossover } \\
\text { design }\end{array}$ & $\begin{array}{l}\text { Negative: } \\
\text { There was no significant difference in the } \\
\text { reduction of systolic blood pressure } \\
\text { between melatonin and placebo, either } \\
\text { with standing or while seated. } \\
\text { The symptom burden was not improved } \\
\text { with melatonin compared with placebo. }\end{array}$ \\
\hline
\end{tabular}


Table 1. Cont.

\begin{tabular}{|c|c|c|c|c|c|}
\hline Target Disease, Reference & Objective & Study Phase & Study Design & Melatonin dosing & Outcomes \\
\hline $\begin{array}{l}\text { Coronary artery bypass } \\
\text { grafting surgery (CABG) [18] }\end{array}$ & $\begin{array}{l}\text { To investigate the effects of } \\
\text { Melatoninon nuclear erythroid } \\
\text { 2-related factor 2(Nrf2) activity in } \\
\text { patients undergoing CABG surgery }\end{array}$ & 2 & $\begin{array}{l}\text { randomized triple-blind } \\
\text { placebo-controlled trial }\end{array}$ & $\begin{array}{l}10 \mathrm{mg} \text { oral melatonin } \\
\text { (Melatonin group, } n=15 \text { ) } \\
\text { or placebo (placebo group, } \\
n=15 \text { ) before sleeping for } \\
1 \text { month before surgery }\end{array}$ & $\begin{array}{l}\text { Positive: } \\
\text { Increase by melatonin of nuclear } \\
\text { erythroid 2-related factor 2(Nrf2) activity } \\
\text { in patients undergoing CABG surgery. }\end{array}$ \\
\hline $\begin{array}{l}\text { Blood coagulation } \\
\text { activity [19] }\end{array}$ & $\begin{array}{l}\text { To investigate if oral administration of } \\
\text { melatonin is associated with decreased } \\
\text { plasma levels of procoagulant } \\
\text { hemostatic measures }\end{array}$ & 2 & $\begin{array}{l}\text { randomized, } \\
\text { placebo-controlled, } \\
\text { single-blinded trial }\end{array}$ & $\begin{array}{l}3 \mathrm{mg} \text { of oral melatonin or } \\
\text { placebo, and one hour } \\
\text { thereafter, levels of } \\
\text { melatonin, fibrinogen, } \\
\text { and D-dimer as well as } \\
\text { activities of coagulation } \\
\text { factor VII (FVII:C) and } \\
\text { VIII (FVIII:C) were } \\
\text { measured in plasma }\end{array}$ & $\begin{array}{l}\text { Positive: } \\
\text { lower levels of the coagulation measures } \\
\text { FVIII:C and fibrinogen one hour after } \\
\text { oral intake of a single dose of } 3 \mathrm{mg} \text { of } \\
\text { melatonin compared to placebo } \\
\text { medication. } \\
\text { Suggested potential implications for the } \\
\text { use of melatonin as a theapeutic agent in } \\
\text { patients at-risk of atherothrombotic } \\
\text { events such as patients with CAD or } \\
\text { systemic hypertension }\end{array}$ \\
\hline
\end{tabular}


Results are awaited from the following completed investigational randomized trials:

Completed trial on prophylactic melatonin treatment for preventive effect on depression, depressive and anxiety symptoms, sleep, and circadian disturbances following acute coronary syndrome (Clinical trials: NCT02451293) [20].

Completed trial on intracoronary and systemic melatonin effects on the Myocardial Salvage Index, high-sensitivity troponin, creatine kinase myocardial band, and clinical events have been investigated in patients with acute myocardial infarction (Clinical trials: NCT01172171) [21].

An ongoing study aims at researching the cardioprotective effects of intravenous melatonin administered prior to reperfusion and continued after restoration of coronary blood flow in patients with ST-segment elevation myocardial infarction undergoing primary percutaneous coronary intervention (Clinical trials: NCT03303378).

\subsection{Coronary Artery Disease}

Melatonin $5 \mathrm{mg}$ in nondippers with coronary artery disease decreased nocturnal blood pressure but also caused a daytime increase [22]. Stipulated mechanisms for the beneficial effects of melatonin in this pathology include an influence on circadian cardiovascular rhythms of blood pressure. Effects of melatonin on progression of coronary artery calcification are being investigated in an ongoing randomized trial (Clinical trials: NCT03966235). The investigators of this study reason that several preclinical studies have shown that melatonin protects against inflammation and apoptosis in vascular calcification (Clinical trials: NCT03966235). However, we were unable to find any published report on melatonin and vascular or coronary artery calcification.

\subsection{Cardiac Arrhythmias}

A clinical intervention trial is underway to evaluate whether melatonin decreases the occurrence of atrial fibrillation after cardiac surgery (Clinical trials: NCT02099331), based on its reported putative antiarrhythmic effects preclinical experimental models [23-25]. A putative antiarrhythmic effect of melatonin has been implicated to occur in preclinical studies by reducing sympathetic tone [26] and its antioxidant activity [27]. In the meantime, a clinical case report suggests that melatonin can potentially induce ventricular arrhythmias [28]. Therefore, the ultimate proarrhythmic vs. antiarrhythmic effect of melatonin awaits to be further clarified in translational studies [28].

\subsection{Heart Failure}

Preclinical studies have documented the beneficial effects of melatonin in reducing myocardial tissue injury in models of experimental ischemia-reperfusion $[29,30]$. Furthermore, the beneficial effects of melatonin in heart failure might be through its effects on cardiovascular health, blood pressure, and endothelial function.

An ongoing trial studies the effect of melatonin $10 \mathrm{mg}$ on cardiovascular and muscle mass and function in patients with heart failure (Clinical trials: NCT03894683).

Melatonin treatment in the perioperative period of major surgery (50 mg melatonin infusion over a $2 \mathrm{~h}$ period intraoperatively, and $10 \mathrm{mg}$ melatonin orally the first three nights after surgery) decreased clinical cardiac morbidity and the occurrence of myocardial ischemia after abdominal aortic aneurism repair (Clinical trials: NCT00315926) [16].

\subsection{Hypertension}

The first indications for melatonin involvement in blood pressure regulations date back in early $70 \mathrm{~s}$ when pinealectomy-induced hypertension that could be prevented with melatonin was described in rats [31,32]. Mechanisms involved could include all presented earlier in this review, but most of the clinical studies are counting on the melatonin's influence on circadian cardiovascular rhythms of blood pressure. Hypertension with circadian alterations of blood pressure, a common cause of cardiac 
complications, has been investigated as a therapeutic target for melatonin. Randomized controlled trials with hypertensive patients reported effects on the following outcome measures:

Decrease in systolic blood pressure throughout the $24 \mathrm{~h}$ period by melatonin $(5 \mathrm{mg}$ oral, 4 weeks) [33].

Increase in 24-h mean blood pressure by melatonin ( $5 \mathrm{mg}$ oral, 4 weeks treatment) in hypertensive patients treated by nifedipine [34].

Decrease in nocturnal blood pressure in patients with untreated essential hypertension by repeated (3 weeks) but not single-dose melatonin ( $2.5 \mathrm{mg}$ ) [35].

Decrease in nocturnal blood pressure in normotensive and treated hypertensive women by melatonin sustained-release (1 $\mathrm{mg}$ rapidly and $2 \mathrm{mg}$ slowly) [36].

Decrease in nocturnal systolic blood pressure in patients with nocturnal hypertension by melatonin sustained-release ( $2 \mathrm{mg}$ for 4 weeks) [37]

Improvement in sleep quality in hypertensive patients treated with beta-blockers by melatonin (2.5 mg for 3 weeks) (ClinicalTrials: NCT00238108) [38].

No significant effect on nocturnal blood pressure in African Americans with essential hypertension by melatonin $24 \mathrm{mg}$ sustained-release was found (Clinical trials: NCT01114373) [39].

A meta-analysis of melatonin effects on nocturnal blood pressure concluded that controlled-release melatonin is effective and safe in ameliorating nocturnal hypertension [40]. Though, the summed up number of patients from these trials was low (149 subjects for fast-release melatonin, 72 subjects for controlled-release melatonin). Also, the dosage was not taken into account.

The conclusions from these trials are awaiting to be reinforced with further phase $2 \mathrm{~b}$ studies to confirm the clinical efficacy of melatonin and determine the therapeutic dose range. Different study populations and time-dependent covariates like sleep apnea should be considered. Further phase 3 randomized controlled trials are necessary to confirm and expand on safety and effectiveness the results from phase 2 trials.

\subsection{Melatonin Receptor Agonists}

Pharmacokinetic parameters of melatonin in humans have been reviewed by Harpsøe NG et al. [41]. No link between specific melatonin plasma concentration levels and actual clinical effects (or adverse effects) has been established yet. Doses of 0.3 to $100 \mathrm{mg}$ of melatonin are typically administered orally, sublingually, or intravenously. Pharmacokinetic parameters, indications, dosing, and common adverse events of commercially available melatonin receptor agonists were summarized by Williams WP 3rd et al. [42]. Common adverse events include nausea, dizziness, and somnolence.

Twelve melatonin receptor small molecules agonists were identified in the ChEMBL bioactivity database, which has $>2$ million compound records created by mining and extracting data from medicinal chemistry literature [43] (Table 2). 
Table 2. ChEMBL Melatonin Agonists. 'ChEMBL ID' = The externally viewed identification for each compound, 'Max Phase' = phase of clinical development, 'QED Weighted' = quantitative estimate of drug-likeness, 'mesh heading' = Medical subject heading (MeSH) assigned to the citation by National Library of Medicine (NLM) indexing, 'melatoninScore' = melatonin potency score is a transformation of the ChEMBL values of activity because they are recorded with different dimensions into a value similar to $-\log$ (potency) in molar scale, which is required to make potency comparisons consistent.

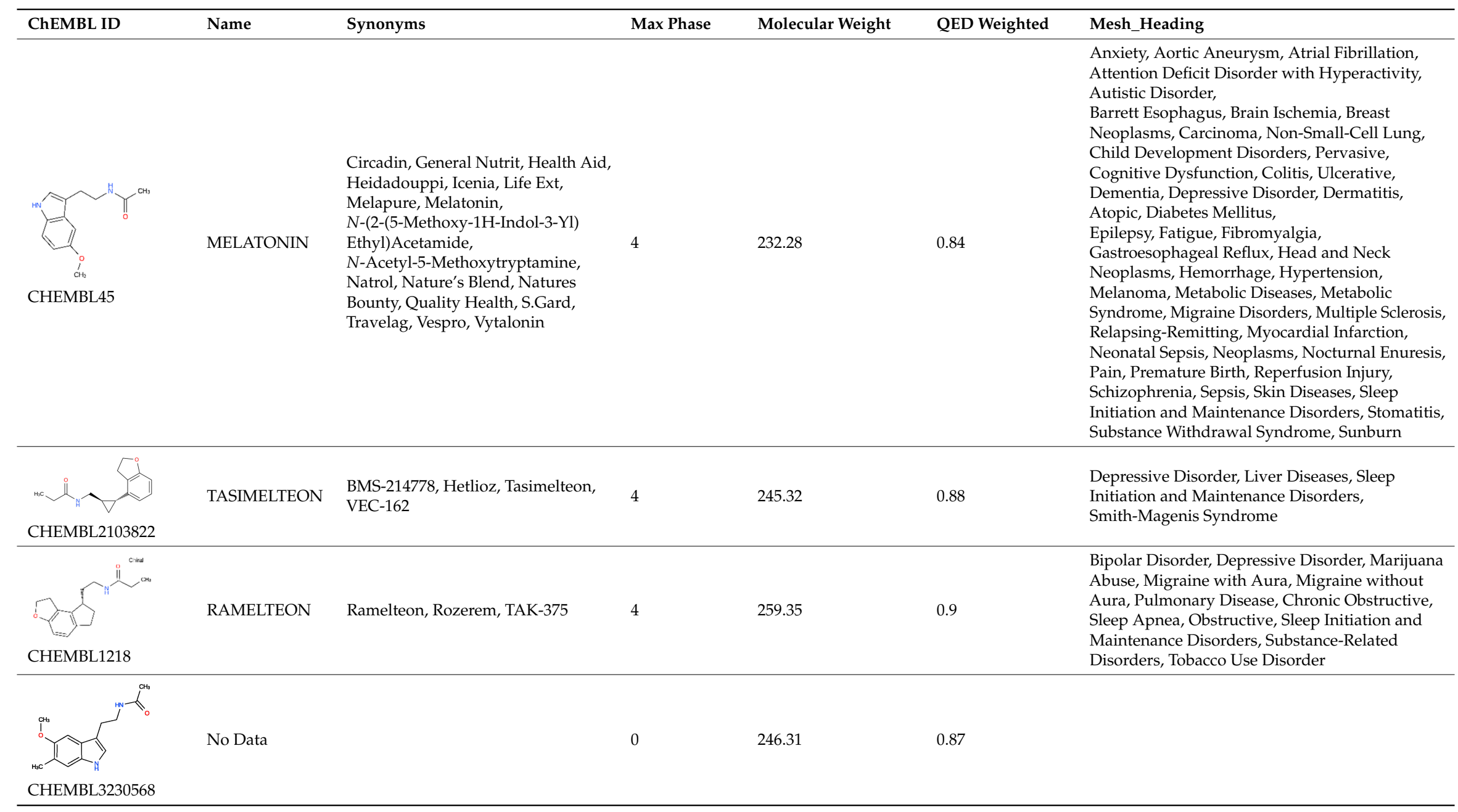


Table 2. Cont

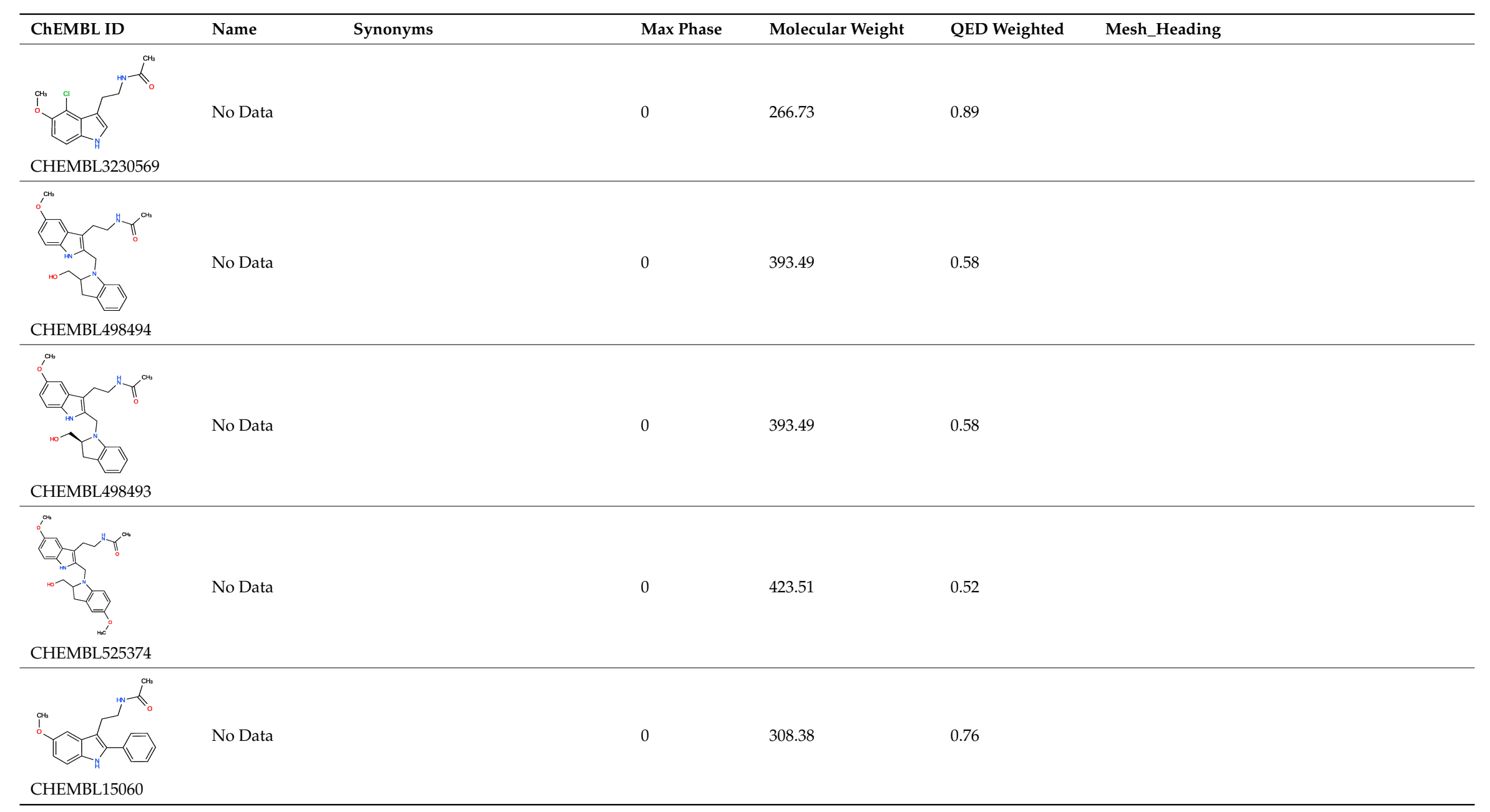


Table 2. Cont

\begin{tabular}{|c|c|c|c|c|c|c|}
\hline ChEMBL ID & Name & Synonyms & Max Phase & Molecular Weight & QED Weighted & Mesh_Heading \\
\hline & No Data & 6-Chloromelatonin & 0 & 266.73 & 0.89 & \\
\hline & No Data & & 0 & 311.18 & 0.91 & \\
\hline & No Data & & 0 & 246.31 & 0.89 & \\
\hline $\mathrm{HE}$ & & & & & & \\
\hline
\end{tabular}


Tasimelteon, a selective dual MT1 and MT2 melatonin receptor agonist, was not investigated in heart or cardiovascular disorders. Tasimelteon is indicated for the treatment of non-24-h sleep-wake disorder (N24HSWD) [44,45], and it is also effective for transient insomnia after sleep-time shift ClinicalTrials: NCT00490945 and NCT00291187) [46]. Tasimelteon was investigated for the treatment of depressive disorder (Clinical trials: NCT01428661), Smith-Magenis syndrome (Clinical trials: NCT02231008), liver diseases (Clinical trials: NCT01271387), without conclusive (published) results.

Ramelteon, a selective dual MT1 and MT2 melatonin receptor agonist, was cardioprotective through postconditioning in a preclinical heart ischemia-reperfusion injury model proof-of-concept study [47]. The cardioprotection induced by Ramelteon is melatonin receptor-dependent and operates through activation of mKCa and mKATP channels [48]. To date, there are no clinical reports of Ramelteon's efficacy on cardiac or cardiovascular diseases. Ramelteon is indicated for the treatment of insomnia [49]. Ramelteon was ineffective for the treatment of bipolar disorder (Clinical trials: NCT01467713) [50].

Agomelatine, (CHEMBL10878) is a melatonergic agonist (at both MT1 and MT2 receptors) and serotonin 2C (5-HT2C) receptor antagonist indicated for the treatment of major depression [51].

Melatonin analogs CHEMBL3230568, CHEMBL3230569, CHEMBL34730, CHEMBL33700 [52], melatonergic ligands CHEMBL498494, CHEMBL498493, CHEMBL525374 [53], selective melatonin MT1 and MT2 agonists CHEMBL15060, CHEMBL34730, CHEMBL33415 [54-58] were reviewed by Zlotos et al. [59].

Two recent papers elucidated the crystal structures and characterized the structural basis of ligand recognition for the human MT1 [60] and MT2 [61] melatonin receptors. MT1 was characterized in complex with four agonists: Ramelteon, two melatonin analogs (CHEMBL15060-2-phenylmelatonin and CHEMBL289233-2-iodomelatonin), and agomelatine (mixed melatonin-serotonin agonist). The MT2 combined with ramelteon and CHEMBL15060 (melatonin analog-2-phenylmelatonin). The X-ray crystal structures of MT1 and MT2 receptors represent a milestone in melatonin research that will facilitate the design of highly selective melatonin lead compounds and therapeutic agents.

\section{Evaluation of Melatonin Cardiovascular Target Tractability and Prediction Using Machine Learning on ChEMBL}

The fundamental step in drug discovery is the generation of a working hypothesis to justify a new lead compound for a therapeutic target. Machine learning models as virtual assays are widely used for compound target prediction and quantitative structure-activity relationship predictions [62]. The ChEMBL database is the largest primary open data source of manually extracted and curated structure-activity relationship data [63,64]. The ChEMBL database contains $5 \mathrm{k}$ records of functional and binding melatonin experiments belonging to 356 different assays carried out in MTR1A, MTR1B, and MTR1C target proteins using 1617 different molecules (Supplement file S1, 'melatoninChemblAssaysUsed' Excel sheet) in 110 citations (Supplement file S2, 'CHEMBL25-chembl_document-aA2WyI' Excel sheet). A melatonin potency score was calculated for them all. Melatonin potency score is a transformation of the ChEMBL values of activity because they are recorded with different dimensions into a value similar to - $\log$ (potency) in molar scale, which is required to make potency comparisons consistent. Given the high correlation between the three receptor MTR1A, MTR1B, and MTR1C subtypes, an average melatonin potency score was used for machine learning purposes (Figure 2, and Supplement file S1, 'activitiesRecordedInChemblByMTR' Excel sheet). For these 1617 compounds, there are $17 \mathrm{k}$ records from $>5 \mathrm{k}$ experimental protocols carried out in a plethora of target-based and phenotypic assays. These records were used as the signature to build our validation set. A final step was the addition of melatonin negative bioactivity data because prediction of activity requires the existence of a population of non-active records [65]. As among the 1617 melatonin related molecules the population of non-active records is almost missing, this was created by adding a $60 \mathrm{k}$ members artificial population from molecules being inactive in at least $10 \mathrm{GPCR}$ assays. The final recorded interactions of our validation set, actives plus autogenerated inactives 
reached $1.5 \mathrm{M}$ data. Variables included in the validation set are related to chemical properties, assay properties, target properties, taxonomy, cell lines, tissues or organs, and some enumerated variables to allow development of random forest algorithms. The validation set incorporated 60 variables describing each experimental fact besides a categorical classification of melatonin activity and a melatonin activity score.
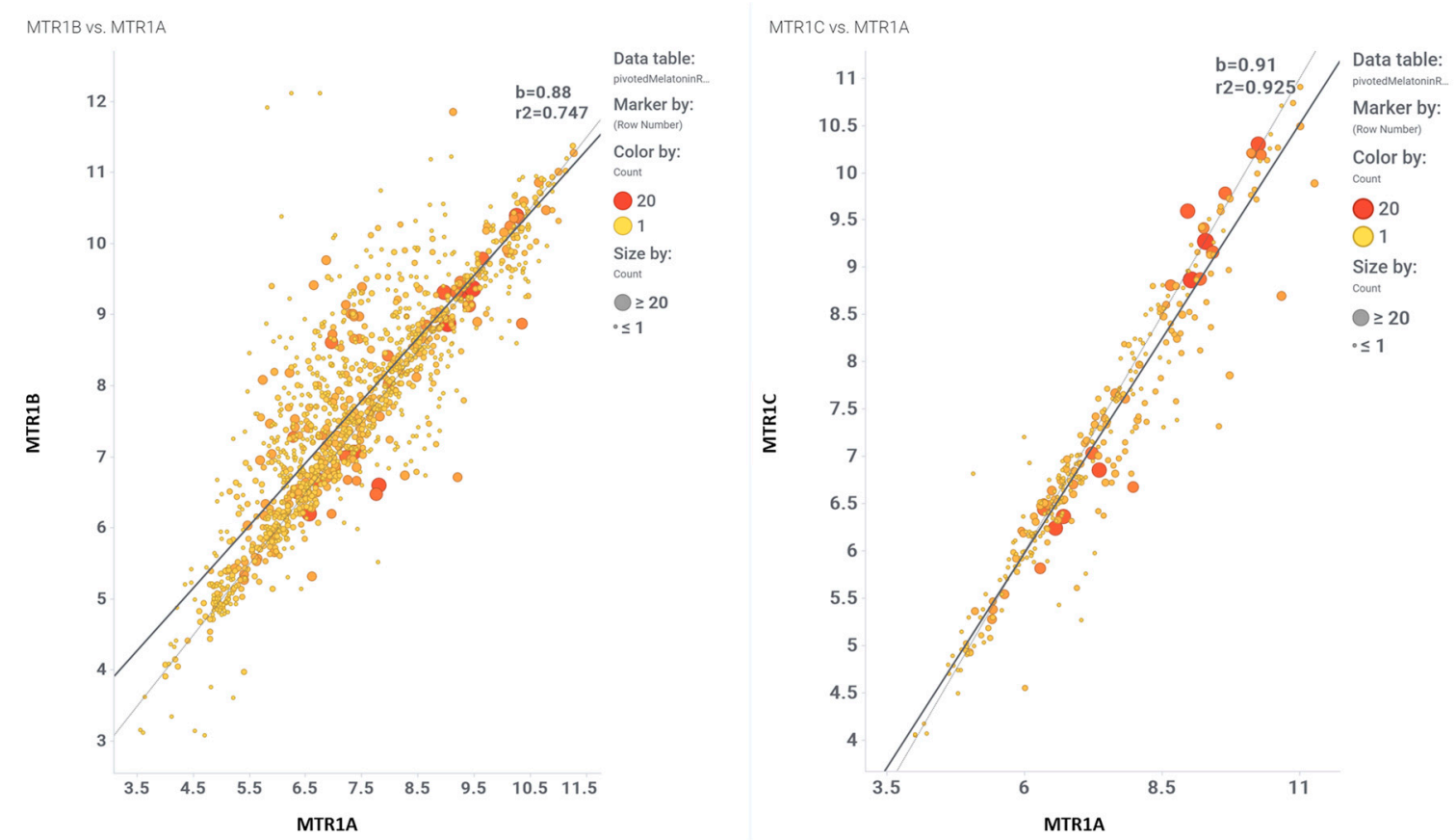

Figure 2. Comparison of the melatonin potency score for MTR1B vs. MTR1A, and MTR1 vs. MTR1A.

Evaluation of predictive models.

The validation set was split in an 80/20 ratio, i.e., training and test sets, respectively (Figure 3). The training set was used to generate random forest classification and regression models [66]. The test set was then passed through the model once the actual melatonin score and labels were removed. This generated a prediction of melatonin prediction upon the $20 \%$ of the validation set records that could be compared to the actual values previously removed, thus allowing prediction quality evaluation. Predictions were then aggregated by compound so that an average activity score by compound was calculated. For classification model, a parameter called countRatio was calculated: basically, the ratio between the occasions a compound is classified active vs. total occasions it appears in the validation set. Figure 4 shows the correlation for regression between the actual and predicted melatonin activity scores (right) and the count ratio. Now, the model can be applied to the whole database records (15 M) and aggregated for the $1.5 \mathrm{M}$ compounds. This is technically a virtual screening campaign. In this step, the calculated melatonin score is a combination of countRatio and melatonin prediction score so that this combination is applied only when no actual score exists. Figure 5 shows the activity distribution histogram for the $1.5 \mathrm{M}$ compounds. If we consider active those with a score $>4$ we have got $9 \mathrm{k}$ hits. Two hundred fifty-four (254) compounds that have a drug name were identified as melatonin active (Supplement file S1, 'drugsIdentifiedAsMelatActive' Excel sheet). In order to see what cardiovascular assays are associated, we used the three main parameters: (1) The melatonin score already defined based on the actual or predicted potency score measured or calculated for melatonin activity; (2) the ChEMBL score, the measured potency score of a molecule in a particular ChEMBL assay; (3) the number of molecules that each particular assay has seen. Selecting ChEMBL scores $>4.5$ in cardiovascular assays, and melatonin scores $>4$, we obtained 284 records from 162 cardiovascular assays carried out with 80 molecules with predicted or measured melatonin activity (Supplement file S1, 284 records are divided in two Excel sheets: 162 records for in vivo assays 'inVivoCVassaysWithMelatoninComp' 
and 122 records for in vitro assays 'inVitroCVassaysWithMelatoninCom'). In Figure 6 the range of the experimental models used in these assays is visualized. Melatonin activities (agonistic or antagonistic) found in these experimental cardiovascular assays and models include arrhythmias, coronary and large vessel contractility, hypertension, and interactions with prazosin and ondansetron.

\section{MACHINE LEARNING SCHEMA}

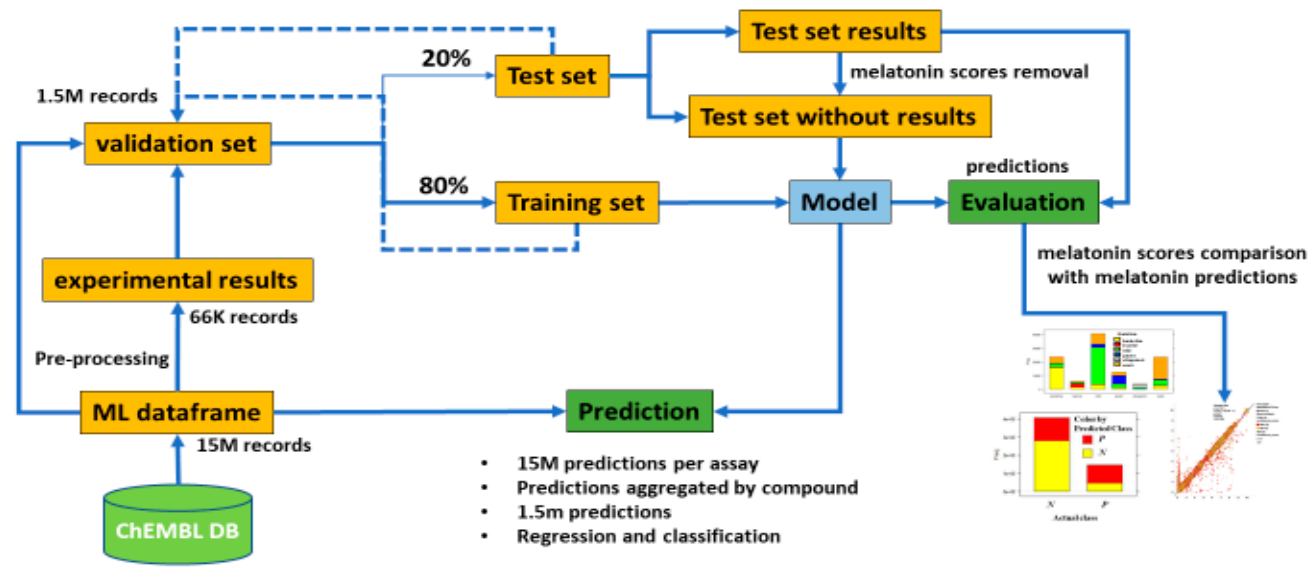

Figure 3. Machine learning schema for melatonin activity.
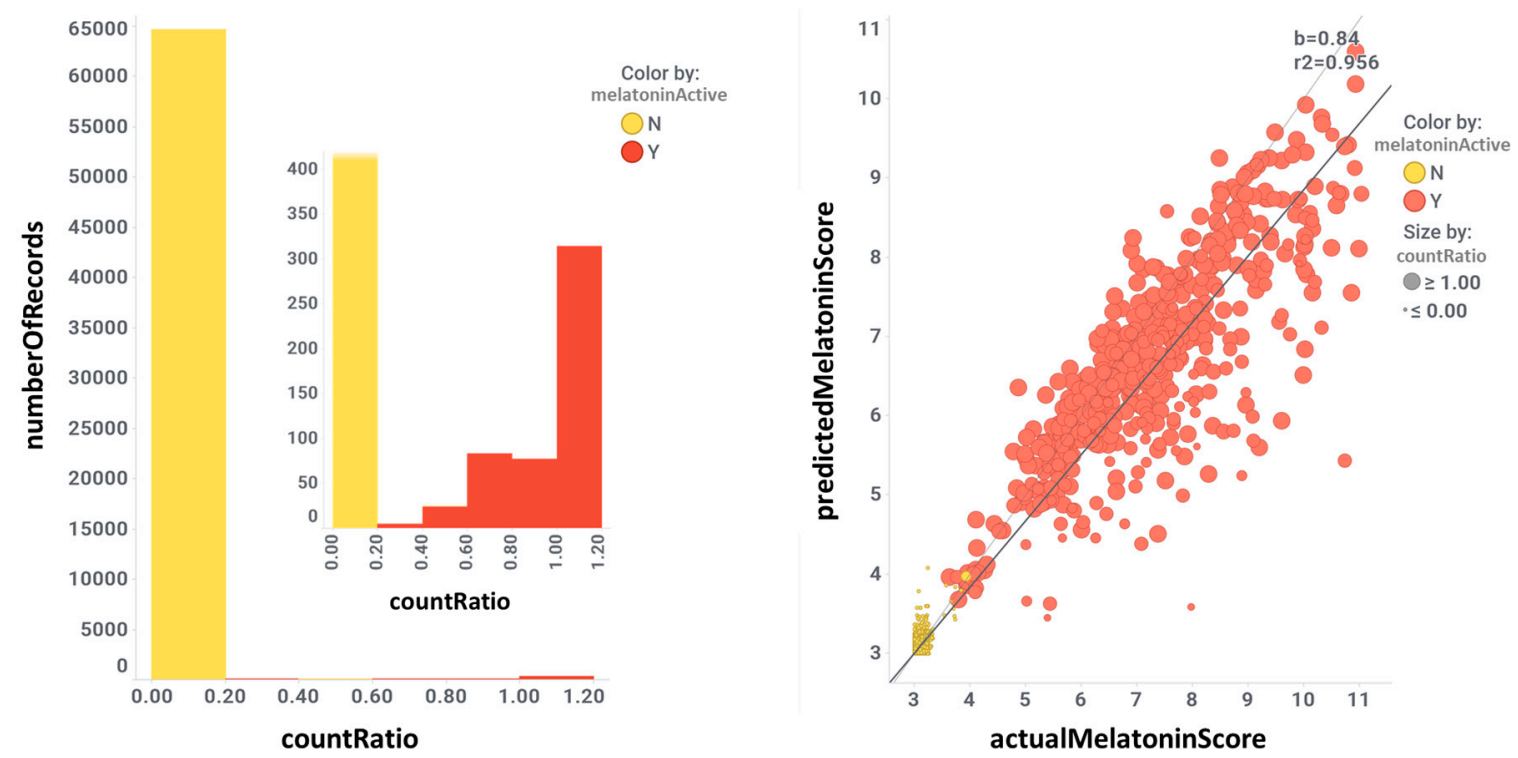

Figure 4. Correlation for regression between the actual and predicted melatonin activity scores (right) and the count ratio. Color is by actual classification label (red = active, yellow = inactive). CountRatio bar chart inset is the same chart zooming in the active zone. 


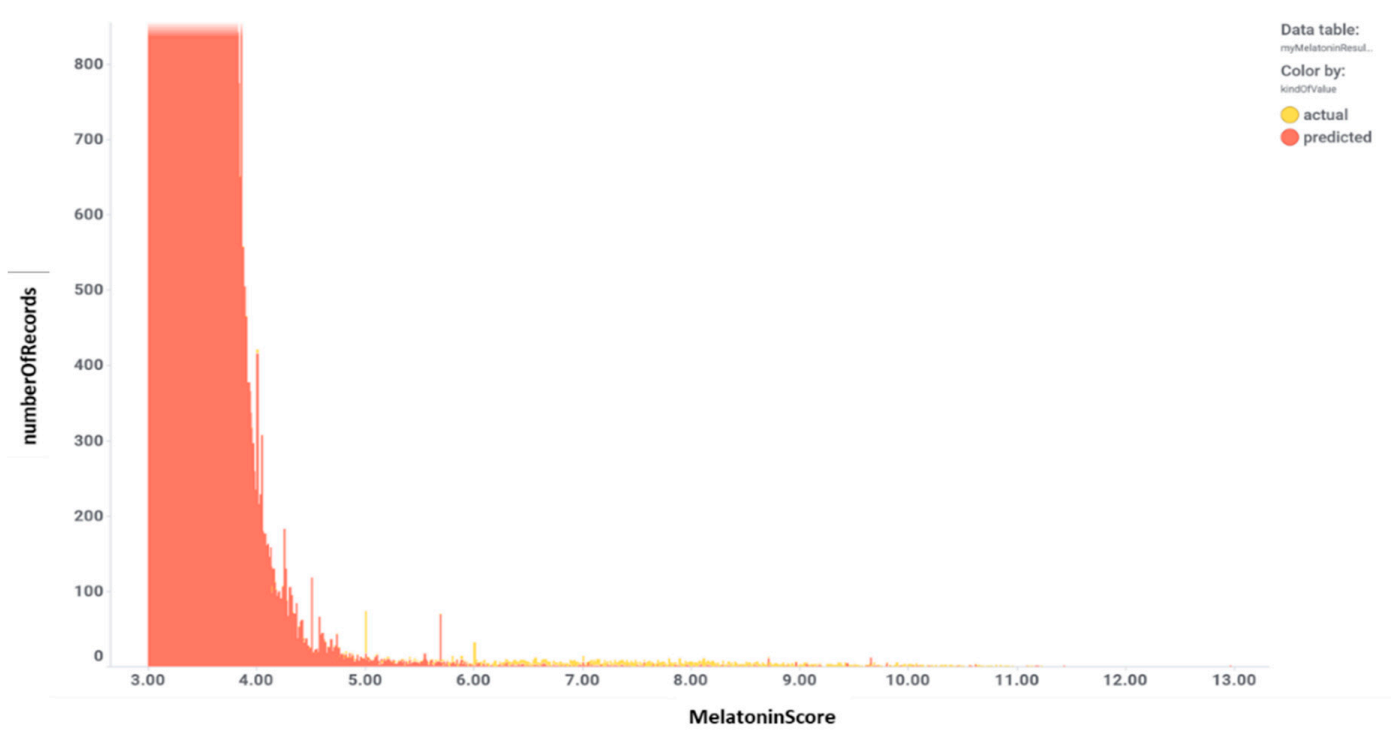

Figure 5. Activity distribution histogram for the $1.5 \mathrm{M}$ compounds.

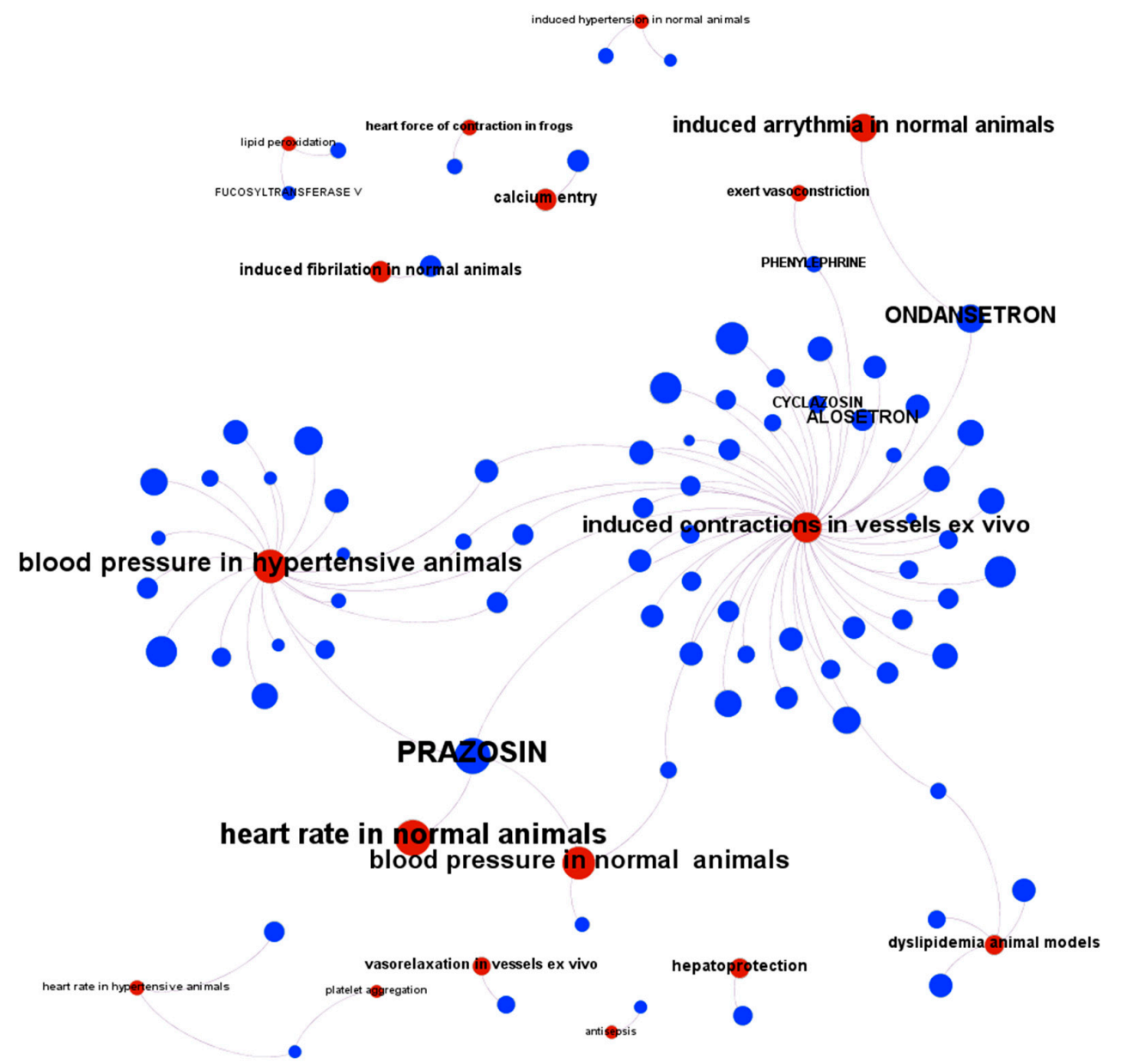

Figure 6. Diagram of the interaction of predicted melatonin active molecules on different models of cardiovascular assays. In red: CV assay model, blue: molecule. When the molecule has a drug name, this name is displayed. When the molecule has a simple registry number it is hidden to allow better visualization. 


\section{Conclusions and Further Directions}

Melatonin, a multifunctional indoleamine, has attributed cardioprotective role through several mechanisms, and apparently has a safe pharmacological profile. Despite the vast preclinical evidence for a cardioprotective and cardiovascular protective melatonin, a better understanding of the pharmacokinetics and pharmacodynamics of melatonin and its associated pharmacophores shall help to translate the basic research findings into a clinical setting.

Melatonin is marketed as a dietary food supplement and commonly prescribed for insomnia [67]. It has not been investigated yet in large-scale, long-term phase $2 b$ and 3 clinical trials. A role of melatonin and its agonists' actions as cardioprotective therapeutic agents shall be established in larger phase 3 randomized interventional studies.

Melatonin receptor agonists have the benefit over melatonin of well-characterized pharmacologic profiles and selective action [42]. Unraveling the X-ray crystal structures of MT1 and MT2 receptors shall lead to the development of highly selective melatonin receptor agonists. Predictive models using machine learning could help in identifying cardiovascular targets for melatonin.

Supplementary Materials: Supplementary materials can be found at http://www.mdpi.com/1422-0067/20/18/ 4342/s1.

Funding: This research was funded by Sao Paulo Research Foundation to JCN (FAPESP 2014/50457-0).

Acknowledgments: OCB and JCN are supported by the National Council for Scientific and Technological Development (CNPq, 307760/2018-9 and 301324/2018-22).

Conflicts of Interest: The authors declare no conflict of interest.

\section{References}

1. Cipolla-Neto, J.; Amaral, F.G.D. Melatonin as a hormone: New physiological and clinical insights. Endocr. Rev. 2018, 39, 990-1028. [CrossRef] [PubMed]

2. Do Amaral, F.G.; Cipolla-Neto, J. A brief review about melatonin, a pineal hormone. Arch. Endocrinol. Metab. 2018, 62, 472-479. [CrossRef] [PubMed]

3. Bouatia-Naji, N.; Bonnefond, A.; Cavalcanti-Proença, C.; Sparsø, T.; Holmkvist, J.; Marchand, M.; Delplanque, J.; Lobbens, S.; Rocheleau, G.; Durand, E.; et al. A variant near MTNR1B is associated with increased fasting plasma glucose levels and type 2 diabetes risk. Nat. Genet. 2009, 41, 89-94. [CrossRef] [PubMed]

4. Jonsson, L.; Ljunggren, E.; Bremer, A.; Pedersen, C.; Landén, M.; Thuresson, K.; Giacobini, M.; Melke, J. Mutation screening of melatonin-related genes in patients with autism spectrum disorders. BMC Med. Genom. 2010, 3, 10. [CrossRef] [PubMed]

5. Campos, L.A.; Cipolla-Neto, J.; Amaral, F.G.; Michelini, L.C.; Bader, M.; Baltatu, O.C. The Angiotensin-melatonin axis. Int. J. Hypertens 2013, 2013, 521783. [CrossRef] [PubMed]

6. Baltatu, O.C.; Amaral, F.G.; Campos, L.A.; Cipolla-Neto, J. Melatonin, mitochondria and hypertension. Cell Mol. Life Sci. 2017, 74, 3955-3964. [CrossRef] [PubMed]

7. Jiki, Z.; Lecour, S.; Nduhirabandi, F. Cardiovascular benefits of dietary melatonin: A myth or a reality? Front. Physiol. 2018, 9, 528. [CrossRef] [PubMed]

8. Ramos, E.; Patiño, P.; Reiter, R.J.; Gil-Martín, E.; López-Muñoz, F.; Romero, A. Melatonin: A hypothesis for Kawasaki disease treatment. Med. Hypotheses 2018, 119, 6-10. [CrossRef] [PubMed]

9. Dominguez-Rodriguez, A.; Abreu-Gonzalez, P.; Avanzas, P. The role of melatonin in acute myocardial infarction. Front. Biosci. 2012, 17, 2433-2441. [CrossRef]

10. Dominguez-Rodriguez, A.; Abreu-Gonzalez, P.; Reiter, R.J. Clinical aspects of melatonin in the acute coronary syndrome. Curr. Vasc. Pharm. 2009, 7, 367-373. [CrossRef]

11. Reiter, R.J.; Tan, D.-X. Melatonin: A novel protective agent against oxidative injury of the ischemic/reperfused heart. Cardiovasc. Res. 2003, 58, 10-19. [CrossRef] 
12. Dominguez-Rodriguez, A.; Abreu-Gonzalez, P.; de la Torre-Hernandez, J.M.; Gonzalez-Gonzalez, J.; Garcia-Camarero, T.; Consuegra-Sanchez, L.; Garcia-Saiz, M.D.M.; Aldea-Perona, A.; Virgos-Aller, T.; Azpeitia, A.; et al. MARIA Investigators Effect of intravenous and intracoronary melatonin as an adjunct to primary percutaneous coronary intervention for acute ST-elevation myocardial infarction: Results of the Melatonin Adjunct in the acute myocaRdial Infarction treated with Angioplasty trial. J. Pineal. Res. 2017, 62. [CrossRef]

13. Dominguez-Rodriguez, A.; Abreu-Gonzalez, P.; de la Torre-Hernandez, J.M.; Consuegra-Sanchez, L.; Piccolo, R.; Gonzalez-Gonzalez, J.; Garcia-Camarero, T.; Del Mar Garcia-Saiz, M.; Aldea-Perona, A.; Reiter, R.J. MARIA Investigators Usefulness of Early Treatment With Melatonin to Reduce Infarct Size in Patients With ST-Segment Elevation Myocardial Infarction Receiving Percutaneous Coronary Intervention (From the Melatonin Adjunct in the Acute Myocardial Infarction Treated With Angioplasty Trial). Am. J. Cardiol. 2017, 120, 522-526. [CrossRef] [PubMed]

14. Shafiei, E.; Bahtoei, M.; Raj, P.; Ostovar, A.; Iranpour, D.; Akbarzadeh, S.; Shahryari, H.; Anvaripour, A.; Tahmasebi, R.; Netticadan, T.; et al. Effects of $\mathrm{N}$-acetyl cysteine and melatonin on early reperfusion injury in patients undergoing coronary artery bypass grafting: A randomized, open-labeled, placebo-controlled trial. Medicine 2018, 97, e11383. [CrossRef] [PubMed]

15. Ekeloef, S.; Halladin, N.; Fonnes, S.; Jensen, S.E.; Zaremba, T.; Rosenberg, J.; Jonsson, G.; Aarøe, J.; Gasbjerg, L.S.; Rosenkilde, M.M.; et al. Effect of Intracoronary and Intravenous Melatonin on Myocardial Salvage Index in Patients with ST-Elevation Myocardial Infarction: A Randomized Placebo Controlled Trial. J. Cardiovasc. Transl. Res. 2017, 10, 470-479. [CrossRef] [PubMed]

16. Gögenur, I.; Kücükakin, B.; Panduro Jensen, L.; Reiter, R.J.; Rosenberg, J. Melatonin reduces cardiac morbidity and markers of myocardial ischemia after elective abdominal aortic aneurism repair: A randomized, placebo-controlled, clinical trial. J. Pineal. Res. 2014, 57, 10-15. [CrossRef] [PubMed]

17. Green, E.A.; Black, B.K.; Biaggioni, I.; Paranjape, S.Y.; Bagai, K.; Shibao, C.; Okoye, M.C.; Dupont, W.D.; Robertson, D.; Raj, S.R. Melatonin reduces tachycardia in postural tachycardia syndrome: A randomized, crossover trial. Cardiovasc. Ther. 2014, 32, 105-112. [CrossRef] [PubMed]

18. Haghjooy Javanmard, S.; Ziaei, A.; Ziaei, S.; Ziaei, E.; Mirmohammad-Sadeghi, M. The effect of preoperative melatonin on nuclear erythroid 2-related factor 2 activation in patients undergoing coronary artery bypass grafting surgery. Oxid. Med. Cell. Longev. 2013, 2013, 676829. [CrossRef]

19. Wirtz, P.H.; Spillmann, M.; Bärtschi, C.; Ehlert, U.; von Känel, R. Oral melatonin reduces blood coagulation activity: A placebo-controlled study in healthy young men. J. Pineal Res. 2008, 44, 127-133. [CrossRef]

20. Madsen, M.T.; Isbrand, A.; Andersen, U.O.; Andersen, L.J.; Taskiran, M.; Simonsen, E.; Gögenur, I. The effect of MElatonin on Depressive symptoms, Anxiety, CIrcadian and Sleep disturbances in patients after acute coronary syndrome (MEDACIS): Study protocol for a randomized controlled trial. Trials 2017, $18,81$. [CrossRef]

21. Halladin, N.L.; Busch, S.E.; Jensen, S.E.; Hansen, H.S.; Zaremba, T.; Aarøe, J.; Rosenberg, J.; Gögenur, I. Intracoronary and systemic melatonin to patients with acute myocardial infarction: Protocol for the IMPACT trial. Dan. Med. J. 2014, 61, A4773. [PubMed]

22. Rechciński, T.; Trzos, E.; Wierzbowska-Drabik, K.; Krzemińska-Pakuła, M.; Kurpesa, M. Melatonin for nondippers with coronary artery disease: Assessment of blood pressure profile and heart rate variability. Hypertens Res. 2010, 33, 56-61. [CrossRef] [PubMed]

23. Tan, D.X.; Manchester, L.C.; Reiter, R.J.; Qi, W.; Kim, S.J.; El-Sokkary, G.H. Ischemia/reperfusion-induced arrhythmias in the isolated rat heart: Prevention by melatonin. J. Pineal Res. 1998, 25, 184-191. [CrossRef] [PubMed]

24. Sahna, E.; Olmez, E.; Acet, A. Effects of physiological and pharmacological concentrations of melatonin on ischemia-reperfusion arrhythmias in rats: Can the incidence of sudden cardiac death be reduced? J. Pineal Res. 2002, 32, 194-198. [CrossRef] [PubMed]

25. Benova, T.; Knezl, V.; Viczenczova, C.; Bacova, B.S.; Radosinska, J.; Tribulova, N. Acute anti-fibrillating and defibrillating potential of atorvastatin, melatonin, eicosapentaenoic acid and docosahexaenoic acid demonstrated in isolated heart model. J. Physiol. Pharm. 2015, 66, 83-89.

26. Blatt, C.M.; Rabinowitz, S.H.; Lown, B. Central serotonergic agents raise the repetitive extrasystole threshold of the vulnerable period of the canine ventricular myocardium. Circ. Res. 1979, 44, 723-730. [CrossRef] 
27. Diez, E.R.; Prados, L.V.; Carrión, A.; Ponce, Z.A.Z.; Miatello, R.M. A novel electrophysiologic effect of melatonin on ischemia/reperfusion-induced arrhythmias in isolated rat hearts. J. Pineal Res. 2009, 46, 155-160. [CrossRef] [PubMed]

28. de Vries, L.J.; Géczy, T.; Szili-Torok, T. Sleep Medications Containing Melatonin can Potentially Induce Ventricular Arrhythmias in Structurally Normal Hearts: A 2-Patient Report. J. Cardiovasc. Pharm. 2017, 70, 267-270. [CrossRef]

29. Yang, Y.; Duan, W.; Jin, Z.; Yi, W.; Yan, J.; Zhang, S.; Wang, N.; Liang, Z.; Li, Y.; Chen, W.; et al. JAK2/STAT3 activation by melatonin attenuates the mitochondrial oxidative damage induced by myocardial ischemia/reperfusion injury. J. Pineal Res. 2013, 55, 275-286. [CrossRef]

30. Şehirli, A.Ö.; Koyun, D.; Tetik, Ş.; Özsavcı, D.; Yiğiner, Ö.; Çetinel, Ş.; Tok, O.E.; Kaya, Z.; Akkiprik, M.; Kılıç, E.; et al. Melatonin protects against ischemic heart failure in rats. J. Pineal Res. 2013, 55, 138-148. [CrossRef]

31. Meneuvonen, P.J.; Karppanen, H. Effects of hydrochlorothiazide, furosemide and ethacrynic acid on pinealectomy-induced hypertension in rats. Ann Med. Exp. Biol. Fenn. 1971, 49, 120-124. [PubMed]

32. Holmes, S.W.; Sugden, D. Proceedings: The effect of melatonin on pinealectomy-induced hypertension in the rat. Br. J. Pharm. 1976, 56, 360P-361P.

33. Lusardi, P.; Preti, P.; Savino, S.; Piazza, E.; Zoppi, A.; Fogari, R. Effect of bedtime melatonin ingestion on blood pressure of normotensive subjects. Blood Press. Monit. 1997, 2, 99-103. [PubMed]

34. Lusardi, P.; Piazza, E.; Fogari, R. Cardiovascular effects of melatonin in hypertensive patients well controlled by nifedipine: A 24-hour study. Br. J. Clin. Pharm. 2000, 49, 423-427. [CrossRef] [PubMed]

35. Scheer, F.A.J.L.; Van Montfrans, G.A.; van Someren, E.J.W.; Mairuhu, G.; Buijs, R.M. Daily nighttime melatonin reduces blood pressure in male patients with essential hypertension. Hypertension 2004, 43, $192-197$. [CrossRef] [PubMed]

36. Cagnacci, A.; Cannoletta, M.; Renzi, A.; Baldassari, F.; Arangino, S.; Volpe, A. Prolonged melatonin administration decreases nocturnal blood pressure in women. Am. J. Hypertens. 2005, 18, 1614-1618. [CrossRef]

37. Grossman, E.; Laudon, M.; Yalcin, R.; Zengil, H.; Peleg, E.; Sharabi, Y.; Kamari, Y.; Shen-Orr, Z.; Zisapel, N. Melatonin reduces night blood pressure in patients with nocturnal hypertension. Am. J. Med. 2006, 119, 898-902. [CrossRef]

38. Scheer, F.A.J.L.; Morris, C.J.; Garcia, J.I.; Smales, C.; Kelly, E.E.; Marks, J.; Malhotra, A.; Shea, S.A. Repeated melatonin supplementation improves sleep in hypertensive patients treated with beta-blockers: A randomized controlled trial. Sleep 2012, 35, 1395-1402. [CrossRef]

39. Rahbari-Oskoui, F.F.; Abramson, J.L.; Bruckman, A.M.; Chapman, A.B.; Cotsonis, G.A.; Johnson, S.A.; Bliwise, D.L. Nighttime administration of high-dose, sustained-release melatonin does not decrease nocturnal blood pressure in African-American patients: Results from a preliminary randomized, crossover trial. Complement Ther. Med. 2019, 43, 157-164. [CrossRef]

40. Grossman, E.; Laudon, M.; Zisapel, N. Effect of melatonin on nocturnal blood pressure: Meta-analysis of randomized controlled trials. Vasc. Health Risk Manag. 2011, 7, 577-584. [CrossRef]

41. Harpsøe, N.G.; Andersen, L.P.H.; Gögenur, I.; Rosenberg, J. Clinical pharmacokinetics of melatonin: A systematic review. Eur. J. Clin. Pharm. 2015, 71, 901-909. [CrossRef] [PubMed]

42. Williams, W.P.T.; McLin, D.E.; Dressman, M.A.; Neubauer, D.N. Comparative Review of Approved Melatonin Agonists for the Treatment of Circadian Rhythm Sleep-Wake Disorders. Pharmacotherapy 2016, 36, 1028-1041. [CrossRef]

43. Griesenauer, R.H.; Schillebeeckx, C.; Kinch, M.S. Assessing the public landscape of clinical-stage pharmaceuticals through freely available online databases. Drug Discov. Today 2019, 24, 1010-1016. [CrossRef] [PubMed]

44. Stahl, S.M. Mechanism of action of tasimelteon in non-24 sleep-wake syndrome: Treatment for a circadian rhythm disorder in blind patients. CNS Spectr. 2014, 19, 475-478. [CrossRef]

45. Neubauer, D.N. Tasimelteon for the treatment of non-24-hour sleep-wake disorder. Drugs Today 2015, 51, 29-35. [CrossRef] [PubMed]

46. Rajaratnam, S.M.; Polymeropoulos, M.H.; Fisher, D.M.; Roth, T.; Scott, C.; Birznieks, G.; Klerman, E.B. Melatonin agonist tasimelteon (VEC-162) for transient insomnia after sleep-time shift: Two randomised controlled multicentre trials. Lancet 2009, 373, 482-491. [CrossRef] 
47. Stroethoff, M.; Behmenburg, F.; Spittler, K.; Raupach, A.; Heinen, A.; Hollmann, M.W.; Huhn, R.; Mathes, A. Activation of melatonin receptors by ramelteon induces cardioprotection by postconditioning in the rat heart. Anesth. Analg. 2018, 126, 2112-2115. [CrossRef] [PubMed]

48. Stroethoff, M.; Christoph, I.; Behmenburg, F.; Raupach, A.; Bunte, S.; Senpolat, S.; Heinen, A.; Hollmann, M.W.; Mathes, A.; Huhn, R. Melatonin Receptor Agonist Ramelteon Reduces Ischemia-Reperfusion Injury Through Activation of Mitochondrial Potassium Channels. J. Cardiovasc. Pharm. 2018, 72, 106-111. [CrossRef]

49. Kuriyama, A.; Honda, M.; Hayashino, Y. Ramelteon for the treatment of insomnia in adults: A systematic review and meta-analysis. Sleep Med. 2014, 15, 385-392. [CrossRef]

50. Mahableshwarkar, A.R.; Calabrese, J.R.; Macek, T.A.; Budur, K.; Adefuye, A.; Dong, X.; Hanson, E.; Sachs, G.S. Efficacy and safety of sublingual ramelteon as an adjunctive therapy in the maintenance treatment of bipolar I disorder in adults: A phase 3, randomized controlled trial. J. Affect. Disord. 2017, 221, 275-282. [CrossRef]

51. De Berardis, D.; Di Iorio, G.; Acciavatti, T.; Conti, C.; Serroni, N.; Olivieri, L.; Cavuto, M.; Martinotti, G.; Janiri, L.; Moschetta, F.S.; et al. The emerging role of melatonin agonists in the treatment of major depression: Focus on agomelatine. CNS Neurol. Disord. Drug Targets 2011, 10, 119-132. [CrossRef] [PubMed]

52. Flaugh, M.E.; Crowell, T.A.; Clemens, J.A.; Sawyer, B.D. Synthesis and evaluation of the antiovulatory activity of a variety of melatonin analogues. J. Med. Chem. 1979, 22, 63-69. [CrossRef] [PubMed]

53. Attia, M.I.; Witt-Enderby, P.A.; Julius, J. Synthesis and pharmacological evaluation of pentacyclic 6a,7-dihydrodiindole and 2,3-dihydrodiindole derivatives as novel melatoninergic ligands. Bioorg. Med. Chem. 2008, 16, 7654-7661. [CrossRef] [PubMed]

54. Spadoni, G.; Stankov, B.; Duranti, A.; Biella, G.; Lucini, V.; Salvatori, A.; Fraschini, F. 2-Substituted 5-methoxy-N-acyltryptamines: Synthesis, binding affinity for the melatonin receptor, and evaluation of the biological activity. J. Med. Chem. 1993, 36, 4069-4074. [CrossRef] [PubMed]

55. Tarzia, G.; Diamantini, G.; Di Giacomo, B.; Spadoni, G.; Esposti, D.; Nonno, R.; Lucini, V.; Pannacci, M.; Fraschini, F.; Stankov, B.M. 1-(2-Alkanamidoethyl)-6-methoxyindole derivatives: A new class of potent indole melatonin analogues. J. Med. Chem. 1997, 40, 2003-2010. [CrossRef]

56. Mor, M.; Rivara, S.; Silva, C.; Bordi, F.; Plazzi, P.V.; Spadoni, G.; Diamantini, G.; Balsamini, C.; Tarzia, G.; Fraschini, F; et al. Melatonin receptor ligands: Synthesis of new melatonin derivatives and comprehensive comparative molecular field analysis (CoMFA) study. J. Med. Chem. 1998, 41, 3831-3844. [CrossRef] [PubMed]

57. Rivara, S.; Mor, M.; Silva, C.; Zuliani, V.; Vacondio, F.; Spadoni, G.; Bedini, A.; Tarzia, G.; Lucini, V.; Pannacci, M.; et al. Three-dimensional quantitative structure-activity relationship studies on selected MT1 and MT2 melatonin receptor ligands: Requirements for subtype selectivity and intrinsic activity modulation. J. Med. Chem. 2003, 46, 1429-1439. [CrossRef]

58. Spadoni, G.; Balsamini, C.; Diamantini, G.; Di Giacomo, B.; Tarzia, G.; Mor, M.; Plazzi, P.V.; Rivara, S.; Lucini, V.; Nonno, R.; et al. Conformationally restrained melatonin analogues: Synthesis, binding affinity for the melatonin receptor, evaluation of the biological activity, and molecular modeling study. J. Med. Chem. 1997, 40, 1990-2002. [CrossRef]

59. Zlotos, D.P.; Jockers, R.; Cecon, E.; Rivara, S.; Witt-Enderby, P.A. MT1 and MT2 melatonin receptors: Ligands, models, oligomers, and therapeutic potential. J. Med. Chem. 2014, 57, 3161-3185. [CrossRef]

60. Stauch, B.; Johansson, L.C.; McCorvy, J.D.; Patel, N.; Han, G.W.; Huang, X.-P.; Gati, C.; Batyuk, A.; Slocum, S.T.; Ishchenko, A.; et al. Structural basis of ligand recognition at the human MT1 melatonin receptor. Nature 2019, 569, 284-288. [CrossRef]

61. Johansson, L.C.; Stauch, B.; McCorvy, J.D.; Han, G.W.; Patel, N.; Huang, X.-P.; Batyuk, A.; Gati, C.; Slocum, S.T.; Li, C.; et al. XFEL structures of the human MT2 melatonin receptor reveal the basis of subtype selectivity. Nature 2019, 569, 289-292. [CrossRef] [PubMed]

62. Rodríguez-Pérez, R.; Miyao, T.; Jasial, S.; Vogt, M.; Bajorath, J. Prediction of compound profiling matrices using machine learning. ACS Omega 2018, 3, 4713-4723. [CrossRef] [PubMed]

63. Davies, M.; Nowotka, M.; Papadatos, G.; Dedman, N.; Gaulton, A.; Atkinson, F.; Bellis, L.; Overington, J.P. ChEMBL web services: Streamlining access to drug discovery data and utilities. Nucleic Acids Res. 2015, 43, W612-W620. [CrossRef] [PubMed]

64. Mendez, D.; Gaulton, A.; Bento, A.P.; Chambers, J.; De Veij, M.; Félix, E.; Magariños, M.P.; Mosquera, J.F.; Mutowo, P.; Nowotka, M.; et al. ChEMBL: Towards direct deposition of bioassay data. Nucleic Acids Res. 2019, 47, D930-D940. [CrossRef] [PubMed] 
65. Mervin, L.H.; Afzal, A.M.; Drakakis, G.; Lewis, R.; Engkvist, O.; Bender, A. Target prediction utilising negative bioactivity data covering large chemical space. J. Cheminform. 2015, 7, 51. [CrossRef] [PubMed]

66. Varnek, A.; Baskin, I. Machine learning methods for property prediction in chemoinformatics: Quo Vadis? J. Chem. Inf. Model. 2012, 52, 1413-1437. [CrossRef] [PubMed]

67. Smith, S.; Vickery, B.; Kouzi, S.; Patel, K. Melatonin use in an inpatient academic medical center: Factors affecting provider documentation of patients' sleep quality. J. Am. Pharm. Assoc. 2019, 59, 533-538. [CrossRef] [PubMed]

(C) 2019 by the authors. Licensee MDPI, Basel, Switzerland. This article is an open access article distributed under the terms and conditions of the Creative Commons Attribution (CC BY) license (http://creativecommons.org/licenses/by/4.0/). 